А. А. Титаренко

\title{
СТРУКТУРНА ОРГАНІЗАЦІЯ УРБАНОНІМІВ КРИВОГО РОГУ
}

Титаренко А. А. Структурна організація урбанонімів Кривого Рогу.

У статті розглянуто структурну будову урбанонімів. Увагу зосереджено на структурній організації урбанонімів Кривого Рогу. Виокремлено прості, складні і складені одиниці.

Ключові слова: структурна організачія, урбанонім, прості, складні і складені найменування.

Титаренко А. А. Структурная организация урбанонимов Кривого Рога.

В статье рассматривается структурное строение урбанонимов. Внимание сосредоточено на структурной организации урбанонимов Кривого Рога. Выделяются простые, сложные и составные названия.

Ключевые слова: структурная организация, урбаноним, простые, сложные и составные названия.

Tytarenko A. A. Structural organization of urbanonims of Kriviy Rih.

The article deals with the structure of urbanonims. It focuses on structural organization of urbanonims of Kriviy Rih. Simple, complex and compound names are distinguished.

Key words: structural organization, urbanonim, simple, complex and compound names.

У сучасному мовознавстві під структурою слова розуміють склад, взаєморозташування i зв'язки його значущих частин. Структурнограматична організація онімів загалом й урбанонімів зокрема неодноразово 
ставала предметом зацікавлення науковців (О. Вінарєва, В. Кам'янець, Р. Ляшенко, О. Суперанська, В. Ткачук). Щоправда, до неї повсякчас звертаються принагідно (Н. Іванова, І. Некіпелова, Т. Топорова). Звідси, відповідно, питання про структуру найменувань внутрішньоміських об'єктів до сьогодні залишається дискусійним. Відсутність систематизації урбанонімів за будовою зумовлює актуальність нашого дослідження.

Метою цієї розвідки є спроба подати опис структурної організації урбанонімів Кривого Рогу.

Не викликає принципових заперечень твердження про те, що структура урбанонімів у різних мовних системах є подібною. Акцентують передусім на плані вираження, кваліфікованому як конструкція, що складається мінімум із двох компонентів: знака-покажчика та пропріальної одиниці. Варіюється лише їхня граматична структура, причому кількість варіантів невелика. 3 позиції граматики повна урбанонімна формула - це завжди атрибутивна синтагма, де елементом, що означає об’єкт, є відповідний покажчик: вулиця, проспект, шосе, бульвар (годоніми); площа (агороніми); фірма, шахта, магазин і т. ін. (ергоніми); а елемент, який є означенням, кваліфікують як пропріальний.

У слов'янській урбанонімії слово-покажчик, або номенклатурний знак, може знаходитися й у препозиції, і в постпозиції 3 більшою частотністю того чи того варіанта в певній мові. До того ж воно пишеться завжди окремо від власної назви.

Структура внутрішньоміського найменування передбачає граматичну характеристику, а саме: якими частинами мови виражені компоненти повної урбанонімної формули і які граматичні засоби й способи зв'язку між ними. Оскільки слово-покажчик атрибутивної конструкції завжди є певним елементом словосполучення, воно зазвичай виражене іменником у називному відмінку (поза мовленнєвою ситуацією). Як свідчить проаналізований фактичний матеріал, належність до лексико-граматичних розрядів прикметника й числівника можуть позначати переважно годоніми.

В урбанонімному просторі Кривого Рогу, як і в українськомовному урбанонімному просторі загалом, годоніми, агороніми, ергоніми, виражені прикметниками або порядковими числівниками, узгоджуються 3 номенклатурним словом у роді й числі (вул. Польова, вул. Степова; провул. Короткий, провул. Червоний; магазин «Цікавий» тощо), можуть мати форму непрямого відмінка (площа Дзержсинського, вул. Дитинства, вул. Юності тощо).

Супровідники ергонімів у спеціальних дослідженнях отримують ○ А. А. Титаренко, 2015. 
так само різну кваліфікацію, як-от: «термін» (Т. Шмельова [11]), «номенклатурний термін» (С. Стародубцева [10]), «родовий термін» (I. Крюкова [4]), «термін-класифікатор» (Е. Ворошилова [2]), «ергонімний термін» (Т. Романова [8]) і т. ін. Крім того, кількість номенклатурних термінів у сфері ергонімії перевищує 300 одиниць [2, с. 13], що загалом не сприяє чіткій систематизації відповідного матеріалу.

Беззаперечним залишається те, що апелятив, який супроводжує власне ім'я, є важливою частиною назви і виконує специфічні функції: «Функція супровідного слова має потрійний характер: на синтаксичному рівні воно, утворюючи разом із власним ім'ям паратактичне поєднання, протиставляється основному тексту; на морфологічному рівні супровідне слово перебирає на себе нерідко відсутні або не повною мірою виражені в онімі функції відміни, уточнення роду тощо» [9, с. 351].

Номенклатурний знак, наявний у складі повного найменування, наприклад, торговельно-комерційного об'єкта, «є носієм найважливішої категорійної інформації (містить відомості про тип установи, профілі діяльності і т. ін.), виконує класифікаційну роль, утілює функцію введення в ряд, без чого власна назва не може існувати» [6, с. 76]. Лексичний номенклатурний компонент, використаний у прямому значенні, повторюється в багатьох найменуваннях певної групи внутрішньоміських об'єктів. Так, скажімо, найменування виробничо-промислових та адміністративно-побутових підприємств супроводжуються такими номенклатурними знаками, як-от: завод, комбінат, підприємство, шахта, агентство, готель, салон тощо.

Зі зміною в Україні форми власності підприємств, у зв'язку 3 появою численних абревіатур (TOB, BAT, 3AT та ін.) змінилася i структура найменування підприємства чи установи: на передньому плані найчастіше знаходяться абревіатури, потім ергонімні компоненти (комбінат, готель, перукарня, магазин тощо), а слідом - власне назва виробничо-промислової, адміністративно-побутової чи торговельнокомерційної організації. Як справедливо зауважує Р. Козлов, номенклатурний термін $\epsilon$ компонентом ергонімів, а їхня загальна структурна схема така: 1) ідентифікатор (стандартизований термін: магазин, BAT, ЗАT, фірма та інші); 2) кваліфікатор (бутик, шинок тощо); 3) диференціатор («Лілія», «№ 123», «Продукти» та інші) [4, с. 8].

3 позиції В. Стародубцевої, номенклатурний термін разом з онімом складають бінарну єдність. Указуючи на спеціалізацію іменованого об'єкта, він найчастіше допомагає визначити мотив найменування останнього [8]. 
Отже, повна урбанонімна структурна організація передбачає наявність двох необхідних компонентів: урбаноніма та термінапокажчика, де перший вирізняється специфічною структурою, яку відтворюють передовсім простими й складними словами; абревіатурами різноманітних типів та словосполученнями.

Дехто 3 науковців робить спробу увиразнити традиційну структурну класифікацію, диференціюючи серед власне урбанонімних найменувань: слова непохідні чи прості похідні, складні, абревіатури складові й звукові, назви, ускладнені цифровою індексацією, апозитиви спеціально створені одиниці номінації, відсутні в загальнолітературній мові, та словосполучення (Т. Хейлик [10]); однокомпонентні та двокомпонентні структурні моделі, описові конструкції (А. Беспалова [1]). Однак із такими підходами можна погодитися не завжди, зокрема, як нам здається, суперечливим $є$ виокремлення так званих непохідних урбанонімів. До того ж їхню систематизацію залежно від структурнограматичної організації варто здійснювати без урахування тих чи тих номенклатурних знаків, або слів-супровідників.

Праці вітчизняних і зарубіжних мовознавців засвідчують: в аспекті структурних класифікацій онімів спостерігається певне ототожнення їх структурної типології з іншими (словотвірною, мотиваційною і т. ін.), що зумовлює іiі часткове ускладнення або спрощення (В. Німчук [5], С. Роспонд [7] та ін.). 3 огляду на це, на нашу думку, структурна градація зазвичай повинна передбачати поділ онімів на групи - прості, складні та складені. Так, у проекті «Українська ономастична термінологія», у якій детально схарактеризовано структуру власних назв, виокремлюються прості (одноосновні), складні (дво- і багатоосновні) та складені (словосполучення або навіть речення) оніми [5, с. 24-43].

Цілком очевидно, виходячи зі значення лексеми «простий», що до розряду простих урбанонімів варто зараховувати елементарні за структурою одиниці (наприклад, ергоніми: «Ажур», «Бомба», «Будуар», «Bіват», «Галантерея», «Сва», «Milavitsa», «ZARINA» тощо).

Прості урбаноніми, як безафіксні, так і афіксальні трапляються доволі часто серед найменувань і лінійних, і масштабних об'єктів. Наприклад, вул. Авіащійна, вул. Аврори, провул. Аджарський, вул. Варлена; площа Визволення, площа Горького, площа Маяковського, площа Толстого; шопоніми: «Бодрум», «Газовик», «Колумбус», «Техновик» тощо.

У цьому плані продуктивністю вирізняються ергонімні найменування, як-от: назви виробничо-промислових та адміністративно-побутових підприємств, або фірмоніми: «Амазонка», «Більшовик», «Ганівський», () А. А. Титаренко, 2015. 


\section{СТРУКТУРА I СЕМАНТИКА МОВНИХ ОДИНИЦЬ}

«Гвардійська», «Глеюватський», "Дискавері», «Південний», «Північний», «Рів'єра», «Тропікана»; назви торговельно-комерційних установ, або шопоніми: "Армавірський», «Асорті», «Барвінок», "Берізка», «Верес», «Віват», «Господарочка», «Данко», «Ера», «Замки», «Ідея», «Комфорт»».

Серед урбанонімних найменувань вирізняються й складні утворення (двокореневі, двоосновні власні назви, що ілюструють поєднання за допомогою інтерфіксів або без): а) вул. Білостоцька, Дніпропетровське шосе, вул.Домнобудівників, вул. Коксохімічна, вул. Лісоводів, вул. Машинобудівельна, вул. Новокриворізька, провул. Новолозуватський, вул. Овочеводів, вул. Семибратова; б) вул. Гулака-Артемовського, вул. Сухе-Батора та ін.. Однак такі одиниці становлять незначну кількість, зокрема серед годонімів, і попри те, що в їхній структурі вирізняється кілька елементів, вони виникли переважно не внаслідок осново- чи словоскладання, а неморфологічними способами творення.

Значно частіше трапляються кількаосновні урбаноніми серед ергонімів, наприклад: «АРТфреш», «СантеХХаус», «Теплокомфорт», «Теплолюкс», «Техношара», «MEGASPORT», «MetalMaster», «TeploLand» тощо. Такі найменування $\epsilon$ зазвичай результатом складноскорочення або складання, рідше - уже готове складноскорочене слово було використане для номінацій промислово-виробничої, адміністративно-побутової чи торговельно-комерційної установи (пор.: «Автограф», «Водограй», «Канцттовари», «Кривбас» і т. ін.).

Серед складних наявні також назви-складання, утворені на основі поєднання: а) того самого слова задля підсилення його значення, синонімічних або співвідносних слів («Буль-Буль», «Тік-Так» «Чисточисто», «Чудо-чадо»); б) слів на позначення однокласових понять «ЗимаЛіто», «Каміни-сауни», «Ковролін-лінолеум», «Хліб-Молоко», «Чай-Кава»; додавання прикладкового компонента: «Бізнес-букет», «Дизайн-меблі», «Роял-Фасон». Спостерігаються й абревіатурні утворення або такі назви, що мають формульне представлення: «ATБ», «KTM», «MTC», «H2O».

Проблема систематизації ускладнюється тим, що в урбанонімному просторі Кривого Рогу спостерігається різнобій у написанні однотипних власних назв, доволі часто норми чинного правопису порушуються: a) написання складноскорочених слів і похідних від них 3 першими частинами аква-, аеро-, медіа-, мега-, техно-, євро-, електро-: «АероДекор», «Аеромагія》, «Аква-Сервіс», «Акватехніка», «Аква-хобі», «ЕкономПлюс», «ЕлектроЛюкс», «Євро-Офіс», «Мега-Люкс»,»Медіасервіс», «Mедіа-сервіс», «Техно Світ»; б) написання складних слів із постпозитивними частинами -ленд, -спорт, -люкс, -сіті: «Бебі-ленд», 
«Драйв-спорт», «Екстрим спорт», «Інтерспорт», «Камея-Люкс», «КАНЦCITY», «ТопЛенд», «Юніор спорт»;в) написання складних слів із препозитивною іншомовною частиною: «Голд-Альянс», «Гранд престиж»; г) написання складних трикомпонентних слів: "АкватермПлюс», «Мінімаркет Плюс», «Технопарк Плюс»; г) неправильне передавання написання запозиченої лексеми: «Уїк Eнд», «Parfum-Prestige» тощо).

Складені урбаноніми передбачають поєднання двох і більше структурних елементів, які $\epsilon$ нарізнооформленими. Такі одиниці трапляються і серед годонімів, і серед ергонімів, причому останні (зі зрозумілих причин) вирізняються більшою продуктивністю.

Складені годоніми передбачають поєднання переважно двох компонентів, які позначають семантично цілісне поняття. Такі одиниці засвідчують імена та прізвища або псевдоніми видатних особистостей світового, вітчизняного та регіонального значення: вул. Аліма Солониченка, вул. Анатолія Жовтухи, вул. Богдана Хмельницького тощо. Рідше - один із компонентів годонімної назви співвідноситься 3 апелятивом (вул. Адмірала Головка, вул. Сержанта Рзянкіна, вул. Сім’ $і$ Демиди), подекуди двокомпонентні найменування лінійних об'єктів маніфестують реалії, які не мають стосунку до конкретної особи або й узагалі не мають стосунку до особи, як-от: Білих Акащій, вул. Біла Гірка, вул. Ветеранів Праці, вул. Червоних Троянд тощо.

Досить продуктивними, як засвідчують результати дослідження, $\epsilon$ складені ергоніми. Такі лінгвоодиниці найчастіше є двокомпонентними атрибутивними сполученнями, де атрибутивний компонент виконує конкретизуючу функцію, може вказувати, скажімо, на виробника тієї чи тієї продукції, як-от: «Гаврилівські курчата», "Свропейські гардини», «Срмолинські напівфабрикати» тощо. У такому разі відносний прикметник обов'язково має формальний показник - суфікс - $c b \kappa$.

Так звані атрибутивні словосполучення становлять різні структурні моделі, зокрема, найактивніше використовуваною є модель «прикметник + іменник»: «Бджолиний світ», «Весела Дача», «Господарські товари», «Дитячий світ» тощо.

Атрибутивно-субстантивні найменування організовані також за моделями «займенник + іменник», «числівник + іменник», причому в ролі числової назви досить часто виступає нумерологічний компонент: «Ваш стиль», «Всяка всячина», «Мій дім», «Наш магазин», "П'ятий Кут», «Твій день», 5 Авеню», «7 кілометр», «12 Вольт», «12 місямів «95 Квартал», «97 Квартал», тощо (пор. модель «кількісний числівник + іменник»: «4 кімнати», «1000 дрібнищь»,, «Сто дрібнищь»).

○ А. А. Титаренко, 2015.

$-216-$ 
У ряді ергонімних найменувань атрибутивні відношення маніфестовані поєднанням двох субстантивів: «Володар Перснів», «Дизайн вогню», «Імперія замків», «Кіт Баюн», «Кониепт Life», «Леді Флора».

Зрідка трапляються назви, що передбачають однорідні сурядні ряди: «Дар $і$ Я», «Дім, сад, город», «Молоко, торти, иукерки», "Овочі $i$ фрукти», "Офіс і ми», «Парфюмерія $і$ галантерея», "Світ \& Стиль і т. ін., що інколи увиразнюються атрибутивним компонентом («Елітна парфумерія $i$ косметика») чи то поєднуються за допомогою діакритичних знаків («Дім + Інтер'єр», «Один + один»).

Поодинокі найменування представлені прийменниковоіменниковими конструкціями, де іменниковий компонент є здебільшого антропонімом: «Від Ольги», «У Людмили», «У Макса», але «Для тебе»; (пор.:«На районі» (жаргонізм), «Відиван» (суржиковий компонент).

Кількакомпонентні ергоніми трапляються рідко і серед українськомовних, і серед нетранслітерних найменувань («Поліна $+B »$, «ПП Бердник С.А.», «Світ швейних машин», "Світ иікавих речей», «Mеtro Cash \& Carry», «Moda Toni Italy»).

3-поміж складених ергонімних найменувань вирізняються запозичення, оформлені i кириличною графікою, i латинською: а) »Анжеліка Лінжері», «Лучіано Карварі», «Міхаїл Воронін»; б) »A. Biaggi Line», "Antonio Gelo», "Fan Shop», "Fashion time», "IQ Fashion», «Marta Vladi», «Yves Rocher» тощо. Проілюстровані ергонімні назви дублюють найменування відомих торговельних марок або апелюють до наслідування тенденцій сучасної моди.

Отже, структурна систематизація урбанонімів передбачає їх поділ на прості, складні та складені з подальшим виокремленням більш дрібних підгруп. Перспективою дослідження є подальша систематизація урбанонімів на підставі інших критеріїв - дериваційних, мотиваційних, етимологічних тощо.

\section{Література}

1. Беспалова А. В. Структурно-семантические модели эргонимов и их употребление в современном английском языке : автореф. дисс. ... канд. филол. наук / А. В. Беспалова. - Одесса, 1989. - 16 с.

2. Ворошилова Е. В. Ономастикон города Канска как отражение истории и культуры народа : автореф. дисс. ... канд. филол. наук / Е. В. Ворошилова. - Тюмень, 2007. $-19 \mathrm{c}$.

3. Крюкова И. В. Рекламное имя : от изобретения до прецедентности : [монография] / И. В. Крюкова. - Волгоград : Перемена, 2004. - 288 с.

4. Козлов Р. И. Эргоурбонимы как новый разряд городской ономастики : 
автореф. дисс. ... канд. филол. наук / Р. И. Козлов. - Екатеринбург, 2000. - 23 с.

5. Німчук В. В. Українська ономастична термінологія (проект) / В. В. Німчук // Повідомлення Української ономастичної комісії. - К. : Наукова думка, 1966. - Вип. 1. - C. 24-43.

6. Романова Т. П. Проблемы современной эргонимии [Электронный ресурс] / T. П. Романова // Dokument HTML. - Режим доступа : http: //www.ssu.samara.ru

7. Роспонд С. Перспективы развития славянской ономастики / С. Роспонд // Вопросы языкознания. - 1962. - № 4. - С. 3-14.

8. Стародубцева В. В. Номинация внутригородских объектов предприятий и учреждений в современном русском языке : на материале ойкодомонимов г. Ульяновска : дисс. ... канд. филол. наук 1 / В. В. Стародубцева. - М., 2003. - 216 с.

9. Старостин Б. А. Пограничные проблемы ономастики / Б. А. Старостин // Ономастика Поволжья. - Вып. 2. - Горький, 1971. - С. 347-352.

10. Хейлик Т. А. Особенности образования эргонимов в современном русском языке / Т. А. Хейлик // Шоста республіканська ономастична конференція : тези допов. і повід. - Ч. 2. - Одеса, 1990. - С. 123-124.

11. Шмелева Т. В. Язык города. Наименования магазинов / Т. В. Шмелева. Красноярск, 1989. - 40 с.

Стаття надійшла до редакиії 17.08.2015 p. 